\title{
Prevalence of HIV, HBV and HCV Infections among Sickle Cell Disease Patients in Southwestern Nigeria: A Case-Control Study
}

\author{
Georgina N. Odaibo1, Oluwatoyin A. Babalola², Onoja M. Akpa3 ${ }^{3}$, Foluke A. Fasola4, \\ Abayomi Odetunde ${ }^{2}$, Biobele Brown ${ }^{5}$, Nanfisat A. Alamukii ${ }^{2}$, Chinedum P. Babalola 6 , \\ Adeyinka G. Falusi'2,7
}

${ }^{1}$ Department of Virology, COM, University of Ibadan, Ibadan, Nigeria

${ }^{2}$ IMRAT, COM, University of Ibadan, Ibadan, Nigeria

${ }^{3}$ Department of Epidemiology and Medical Statistics, COM, University of Ibadan, Ibadan, Nigeria

${ }^{4}$ Department of Haematology, COM, University of Ibadan, Ibadan, Nigeria

${ }^{5}$ Department of Paediatrics, COM, University of Ibadan, Ibadan, Nigeria

${ }^{6}$ Department of Pharmaceutical Chemistry, COM, University of Ibadan, Ibadan, Nigeria

${ }^{7}$ Sickle Cell Hope Alive, Foundation (SCHAF), Ibadan, Nigeria

Email: ^foreodaibo@hotmail.com

How to cite this paper: Odaibo, G.N. Babalola, O.A., Akpa, O.M., Fasola, F.A., Odetunde, A., Brown, B., Alamukii, N.A., Babalola, C.P. and Falusi, A.G. (2021) Paper Title. World Journal of AIDS, 11, 101119.

https://doi.org/10.4236/wja.2021.113009

Received: May 14, 2021

Accepted: September 5, 2021

Published: September 8, 2021

Copyright $\odot 2021$ by author(s) and Scientific Research Publishing Inc. This work is licensed under the Creative Commons Attribution International License (CC BY 4.0).

http://creativecommons.org/licenses/by/4.0/

(c) (i) Open Access

\begin{abstract}
Aim: This study was designed to determine the prevalence of HBV, HCV and HIV infections among individuals with Sickle Cell Disease (SCD) in Ibadan, southwestern Nigeria. Methodology: In this case-control study, 1017 patients with SCD and 1017 age and gender matched controls were enrolled from 6 health facilities and some communities in Ibadan, southwestern Nigeria. Blood samples were tested for the presence of HIV, HBV and HCV infections. Structured questionnaire was used to capture participants' information and data analyzed using descriptive statistics, McNemar Chi-square/Fishers exact test. Results: Blood transfusion was significantly more common among SCD cases [566 (55.7\%)] than controls [54 (5.3\%)], while history of vaccination was higher in the control group $(\mathrm{p}=0.001)$. The overall prevalence of HIV [2 $(0.2 \%)$ vs $11(1.1 \%)$ ], HBV [58 (5.7) vs $66(6.5 \%)$ ] and HCV [10 (1.0) vs $22(2.2 \%)]$ was lower among SCD cases than controls, respectively, although significantly different only in HCV infection $(\mathrm{p}=0.048)$. All three infections were significantly higher in adults than in children. Co-infection was found only in four of the participants, all of whom were SCD patients. Conclusion: The prevalence of HIV, HBV and HCV infection among SCD patients indicates an improvement in the transfusion safety measures in the region. The prevalence of $\mathrm{HBV}$ and $\mathrm{HCV}$ found in this study is still relatively high when compared with reports from some other regions. There is a need for continued surveillance
\end{abstract}


and subsidized cost of drugs for treatment of these infections, especially for SCD patients who already have a compromised immunity.

\section{Keywords}

Hepatitis B, Hepatitis C, Human Immunodeficiency Virus, Sickle Cell Disease, Prevalence

\section{Introduction}

Sickle cell disease (SCD) is defined as the condition resulting from the inheritance of sickle hemoglobin from both parents or sickle hemoglobin from one parent and another pathological variant hemoglobin from the other parent [1]. It is one of the most common inherited anaemias globally and the most prevalent genetic disease in Nigeria [2]. Nigeria has the highest burden of SCD in the world with a prevalence of $2 \%$ to $3 \%$ [2] [3]. Over 4 million individuals have homozygous $\mathrm{HbS}$, while another 40 million have sickle cell trait [4]. Some of the major complications of SCD in most patients are chronic anaemia and infection, which are major causes of death and disability, although increased susceptibility to these infections is still poorly understood [3] [5]. Due to the chronic anaemia, blood transfusion is a major therapeutic and prophylactic intervention in the management of patients with SCD. Frequent transfusion exposes SCD patients to blood borne pathogens [5] [6] most of which are viruses such as hepatitis B virus (HBV), hepatitis $\mathrm{C}$ virus (HCV), human immunodeficiency virus (HIV) and other transfusion transmitted viruses (TTV). These infections are major health problems in developing and resource limited countries including Nigeria [7] [8].

Human immunodeficiency virus, an RNA virus is a member of the genus lentivirus of the family retroviridae while hepatitis $\mathrm{B}$ virus is a DNA virus belonging to the family hepadnaviridae and hepatitis $C$ virus also an RNA virus is of the genus hepacivirus, a member of the family flaviviridae. HIV and HBV utilises the enzyme reverse transcriptase for their replication to convert RNA to DNA. These viruses share common routes of transmission [5] [9] that include: parenteral (through unscreened blood), sexual (horizontal), mother to infant (vertical) and intra-familial spread (horizontal transmission). Due to shared routes of transmission, coinfection with HIV and viral hepatitis is common [8] [9] [10] [11]. Interestingly the rates of these three infections are high, if not highest in Sub-Saharan Africa where SCD is also prevalent. According to UNAIDS 2018 estimates, the prevalence of HIV infection varies from $0.3 \%$ to $23 \%$ in Madagascar and Lesotho, respectively, with Nigeria $(2,600,000)$ and South Africa $(7,700,000)$ having the largest number of people living with the infection globally [12]. WHO estimates that over 257 million people are living with chronic hepatitis B globally, although only $10.5 \%$ of these infected individuals know their HBV status [13]. In Africa about $6.1 \%$ of the adult population are infected with HBV, with Nigeria being one of the countries classified as being highly endemic (i.e. HBV preva- 
lence $>8 \%$ ) [14]. Worldwide more than 170 million persons have HCV infection, of whom 71 million have chronic infection [15] [16]. The eastern Mediterranean countries have the highest prevalence of $2.3 \%$, with other regions having an estimated prevalence of $0.5 \%-1.5 \%$. In Nigeria previous studies on HCV have reported a prevalence of $0.5 \%-15 \%$, from different parts of and various population groups in the country [17] [18] [19] [20].

There is no approved vaccine currently available against HCV and HIV infection, while highly effective vaccines are available to prevent HBV infection. In Nigeria HBV vaccine was included in the National Programme on Immunization (NPI) in 2004 [21], implying that a large proportion of children born after 2004 have been vaccinated against HBV infection. Although effective drugs for the treatment of $\mathrm{HBV}$ and $\mathrm{HCV}$ are available, they are still relatively expensive and not within the reach of a large percentage of the patients in Nigeria and other resource limited countries [22] [23]. On the other hand, although there is increasing access to antiretroviral therapy (ART) even in the developing countries due to donor support, treatment for HIV is not curative [12]. Hence the most effective way of controlling these infections is through prevention. Information on the prevalence of these viruses is important for planning of health control measures in primary and secondary prevention, particularly as HBV and HCV could result in chronic liver disease with long term risk of liver cirrhosis and hepatocellular cancer [24] [25]. Also, HIV infection could further compromise the already deficient immune status of the SCD population [26]. This study was therefore designed to determine the rate of HBV, HCV and HIV infections among individuals with and without SCD in Ibadan, southwestern Nigeria.

\section{Materials and Methods}

\subsection{Study Area}

The study was carried out in Ibadan, a metropolitan city, and the capital of Oyo State, Nigeria [https://www.britannica.com/place/Ibadan]. Ibadan has over 3 million inhabitants. Being one of the most populous cities in Nigeria, Ibadan is the largest geographical municipal area in Nigeria with a high population density of $985.13 / \mathrm{km}^{2}$ (2551.5/sq mi). The study was conducted in the tertiary, secondary and other recognized health facilities that serve as referral centers for SCD in Oyo State as well as other States within the Southwestern region of Nigeria.

\subsection{Study Design and Data Collection}

This was a case control, cross-sectional study. Participants with SCD (cases) were enrolled after obtaining their consent during their routine visit to the SCD clinic in some health facilities. Cases were only enrolled in health facilities that have well-established SCD clinics and are reputed referral centers in Oyo State. These facilities include the University College Hospital, Ibadan; Adeoyo Maternity Teaching Hospital, Ibadan; State Hospital Ring Road, Oni Memorial Hospital, Ibadan Sickle Cell Foundation, Adeoyo Maternity Centre, University of Ibadan Jaja Clinic, Ibadan. Participants without SCD (controls) were recruited 
during outreach programs at community levels from schools and communities using these referral hospitals and around the hospitals and clinics where cases were sourced within the Ibadan Metropolis. The same questionnaire that captured information on sociodemographic and behavioral characteristics and medical history was administered to both cases and controls by trained interviewers. Ethical approval for the study was obtained from UI/UCH Institutional Review Board (approval \# UI/EC/17/0400, 28-12-17, 28-12-18, 28-12-19, 26-122020 ) and all aspects of the study were carried out in accordance with the ethical standards of the Declaration of Helsinki. Group pre-test counseling was offered to participants before sample collection. Their test results were given to them in a one-on-one post-test counseling session during which positive individuals were referred to the appropriate clinics. HIV positive individuals were referred to the ART clinic, while HBV/HCV positive individuals were referred to the gastroenterology clinic.

\section{Inclusion Criteria}

- Only those who had been diagnosed with SCD and were tested using the phenotypically accurate HPLC diagnostic system to confirm the presence of either haemoglobin SS or SC at the Genetics Research Unit.

- Controls were individuals with HPLC confirmed phenotypes indicating no who do not have SCD, and are community or hospital-based and from the same communities within the catchment areas of the hospital where cases were recruited.

- Hospital-based controls were patients at general outpatients (GOP), medical outpatient (MOP) and children outpatient (CHOP) clinics of the participating health centres.

Eligible cases or controls must have given written informed consent, assent or parental/caregiver consent (for children who cannot give assent) before enrolment into the study.

\section{Exclusion Criteria}

- Individuals who were pregnant at the point of recruitment were excluded from the study.

\subsection{Sample Collection, Processing and Storage}

Five milliliters of venous blood were collected into $2 \mathrm{ml}$ and $3 \mathrm{ml}$ aliquot bottles containing EDTA from each participant after obtaining their informed consent or assent (for minors) and a pre-test counseling. Both aliquots of blood were transported in a cold box from the site of collection to the University College Hospital. The $2 \mathrm{ml}$ aliquot was delivered to the Genetics Research Laboratory at the Institute for Advanced Medical Research \& Training (IAMRAT) for haemoglobin phenotype confirmation using the Biorad Variant 2 High Performance Liquid Chromatography (HPLC). The $3 \mathrm{ml}$ aliquot was delivered to the Department of Virology, College of Medicine, both at the UCH, University of Ibadan. At the Virology Department, the $3 \mathrm{ml}$ aliquot was centrifuged at $3000 \mathrm{rpm}$ for 15 mins, plasma separated and stored in aliquots in $-20^{\circ} \mathrm{C}$ until analysed. A total of 
1017 blood samples were collected from SCD Cases and 1017 samples from NonSCD Controls. A structured questionnaire was used to capture demographic and some medical information.

\subsection{Laboratory Analysis}

Stored plasma samples were tested for the presence of HIV, HBV and HCV using commercially available $3^{\text {rd }}$ and $4^{\text {th }}$ generation ELISA kits in an internationally accredited ISO 15189 (SANAS) laboratory in the Department of Virology. Heamoglobin confirmation, analyses and quantification of study samples into Cases and Controls were carried out using the SweLab Alpha 3 Cell Counter and the Bio-Rad HLPC at the Genetics Research lab also an accredited laboratory at the College of Medicine, University of Ibadan.

\subsubsection{Diagnosis of HIV Infections}

Plasma samples were tested for the presence of HIV-1/2 infection using a fourth generation ELISA (GenScreen Ultra HIV Ag-Ab, Bio-Rad, Paris) that has the ability of detecting both HIV antigen and antibodies. Initially reactive samples were repeated using the same assay, and repeatedly reactive samples were further analysed by Western blot technique to confirm infection. The bands on the Western blot strips were identified by comparing them to the bands on the positive control strip and results interpreted as follows: No band present: HIV-1 and HIV-2 negative; any two or more bands including any of the glycoproteins and a gag protein band: HIV positive; any band pattern not matching the criteria for positive HIV result: indeterminate.

\subsubsection{Diagnosis of HBV Infections}

HBV diagnosis was made using ELISA that detects surface antigen (Monolisa, Bio-Rad, Paris) or IgM antibodies to the core antigen (HBcIgM, Dia.PRO, Italy). All assays were performed according to manufacturer recommendation. Samples that were positive for either HBsAg or HBcIgM were considered positive for hepatitis $B$ virus infection.

\subsubsection{Diagnosis of HCV Infections}

A third generation ELISA (HCV-Ab, Dia.PRO, Italy) that detects $\mathrm{HCV}$ antibodies was used for diagnosis of HCV infection.

\subsection{Data Analysis}

Data were analysed using descriptive statistics, McNemar Chi-square/Fishers exact test with IBM SPSS statistics version 25.

\section{Results}

A total of 2034 participants were enrolled for the study, including 1017 cases and 1017 controls. Table 1 shows the demographic and some medical history of the study participants. There was no difference in the sex $(p=0.99)$ and age $(p=$ 0.50 ) distribution between the two groups. There was, however, a significant dif- 
ference in the history of blood transfusion $(\mathrm{p}<0.001)$ and history of HBV vaccination ( $p=0.001)$, with a higher rate of blood transfusion $(55.7 \%)$ among individuals with SCD. On the other hand, the proportion of individuals who had HBV vaccination was higher $(p=0.001)$ among those without $S C D$. The male to female ratio for both groups was approximately 1.1:1.

Table 1. Characteristics of study population.

\begin{tabular}{|c|c|c|c|c|}
\hline CHARACTERISTICS & CASES & CONTROL & TOTAL & $\mathrm{p}$ \\
\hline \multicolumn{5}{|l|}{ Sex } \\
\hline Male & $527(51.8)$ & $528(51.9)$ & $1055(51.9)$ & \multirow[t]{3}{*}{$\# \#$} \\
\hline Female & $490(48.2)$ & $489(48.1)$ & $979(48.1)$ & \\
\hline Total & 1017 & 1017 & 2034 & \\
\hline \multicolumn{5}{|l|}{ Age } \\
\hline $0-9$ yrs & $305(30.0)$ & $344(33.8)$ & $649(31.9)$ & \multirow[t]{7}{*}{0.50} \\
\hline $10-19 y r s$ & $346(34.0)$ & $330(32.4)$ & $676(33.2)$ & \\
\hline $20-29 y r s$ & $207(20.4)$ & $201(19.8)$ & $408(20.1)$ & \\
\hline $30-39$ yrs & $99(9.7)$ & $84(8.3)$ & $183(9.0)$ & \\
\hline $40-49$ yrs & $37(3.6)$ & $33(3.2)$ & $70(3.4)$ & \\
\hline 50 yearst & $23(2.3)$ & $25(2.5)$ & $48(2.4)$ & \\
\hline Total & 1017 & 1017 & 2034 & \\
\hline \multicolumn{5}{|l|}{ Study Centre } \\
\hline CHOP & $274(26.9)$ & $63(6.2)$ & $337(16.6)$ & \multirow[t]{9}{*}{$<0.001$} \\
\hline RRSH & $171(16.8)$ & $6(0.6)$ & $177(8.7)$ & \\
\hline HAEMATOLOGY & $247(24.3)$ & $118(11.6)$ & $365(17.9)$ & \\
\hline $\mathrm{OMCH}$ & $173(17.0)$ & $4(0.4)$ & $177(8.7)$ & \\
\hline$I B S C F$ & $105(10.3)$ & $36(3.5)$ & $141(6.9)$ & \\
\hline$A M T H$ & $19(1.9)$ & $41(4.0)$ & $60(2.9)$ & \\
\hline COMMUNITY & $13(1.3)$ & $747(73.5)$ & $760(37.4)$ & \\
\hline JAJA CLINIC UI & $15(1.5)$ & $2(0.2)$ & $17(0.8)$ & \\
\hline TOTAL & 1017 & 1017 & 2034 & \\
\hline \multicolumn{5}{|c|}{ History of blood transfusion } \\
\hline Yes & $566(55.7)$ & $54(5.3)$ & $620(30.5)$ & \multirow[t]{3}{*}{$<0.001$} \\
\hline No & $451(44.3)$ & $963(94.7)$ & $1414(69.5)$ & \\
\hline Total & 1017 & 1017 & 2034 & \\
\hline \multicolumn{5}{|c|}{ History of HBV Vaccination } \\
\hline Yes & $229(22.5)$ & $296(29.1)$ & $525(25.8)$ & \multirow[t]{5}{*}{0.001} \\
\hline No & $778(76.5)$ & $715(70.3)$ & $1493(73.4)$ & \\
\hline I don't Know & $4(0.4)$ & $0(0.0)$ & $4(0.2)$ & \\
\hline Not Applicable & $6(0.6)$ & $6(0.6)$ & $12(0.6)$ & \\
\hline Total & 1017 & 1017 & 2034 & \\
\hline
\end{tabular}

\#\# - No p-value because the cases and controls were matched exact sex. 
The overall prevalence of HIV, HBV and $\mathrm{HCV}$ infections was $0.6 \%, 6.1 \%$ and $1.6 \%$, respectively (Figure 1). The prevalence of HIV and HCV infections were higher among the controls $(\mathrm{p}=0.12 \& 0.03$ respectively), while there was no significant difference in the prevalence of HBV $(\mathrm{p}=0.52)$ infection between the cases and controls.

Table 2 shows the distribution of HIV infection by gender and age of the participants. Out of the 2034 participants tested 13 were positive for HIV giving an overall prevalence of $0.6 \%$. Although there was no difference in prevalence among males and females within each of the groups, the prevalence of infection was

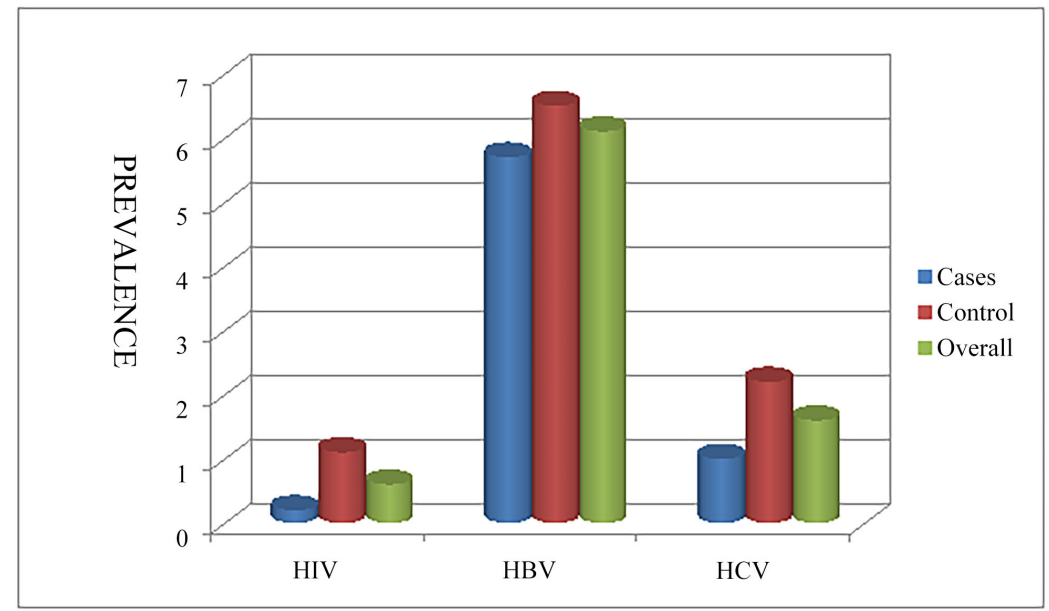

Figure 1. Prevalence of HIV, HBV and HCV among individuals with and without Sickle Cell Disorder.

Table 2. Distribution of HIV by gender and age group among individuals with or without SCD in Southwestern Nigeria.

\begin{tabular}{|c|c|c|c|c|c|c|c|c|}
\hline & & \multicolumn{2}{|c|}{ CASES } & \multicolumn{2}{|c|}{ CONTROL } & \multicolumn{2}{|c|}{ TOTAL } & \multirow[t]{2}{*}{$p$ value } \\
\hline & & $\begin{array}{c}\text { No } \\
\text { Tested }\end{array}$ & $\begin{array}{l}\text { No }(\%) \\
\text { positive }\end{array}$ & No Tested & $\begin{array}{l}\text { No }(\%) \\
\text { positive }\end{array}$ & No Tested & $\begin{array}{l}\text { No (\%) } \\
\text { positive }\end{array}$ & \\
\hline \multirow{3}{*}{ Gender } & Male & 527 & $0(0.0)$ & 528 & $7(1.3)$ & 1055 & $7(0.7)$ & 0.02 \\
\hline & Female & 490 & $2(0.4)$ & 489 & $4(0.8)$ & 979 & $6(0.6)$ & 0.45 \\
\hline & Total & 1017 & $\begin{array}{c}2(0.2) \\
p=0.23\end{array}$ & 1017 & $\begin{array}{l}11(1.1) \\
p=0.55\end{array}$ & 2034 & $\begin{array}{l}13(0.6) \\
p=0.99\end{array}$ & 0.02 \\
\hline \multirow{7}{*}{$\begin{array}{l}\text { Age } \\
\text { group }\end{array}$} & $0-9$ & 305 & $1(0.3)$ & 344 & $2(0.6)$ & 649 & $3(0.5)$ & 0.99 \\
\hline & $10-19$ & 346 & $0(0.0)$ & 330 & $3(0.9)$ & 676 & $3(0.4)$ & 0.12 \\
\hline & $20-29$ & 207 & $0(0.0)$ & 201 & $2(1.0)$ & 408 & $2(0.5)$ & 0.24 \\
\hline & $30-39$ & 99 & $1(1.0)$ & 84 & $1(1.2)$ & 183 & $2(1.1)$ & 0.99 \\
\hline & $40-49$ & 37 & $0(0.0)$ & 33 & $2(6.1)$ & 70 & $2(2.9)$ & 0.22 \\
\hline & $\geq 50$ & 23 & $0(0.0)$ & 25 & $1(4.0)$ & 48 & $1(2.1)$ & 0.99 \\
\hline & Total & 1017 & $\begin{array}{c}2(0.2) \\
p=0.26\end{array}$ & 1017 & $\begin{array}{l}11(1.1) \\
p=0.07\end{array}$ & 2034 & $\begin{array}{l}13(0.6) \\
p=0.96\end{array}$ & 0.02 \\
\hline
\end{tabular}


higher $(\mathrm{p}=0.02)$ among the male controls compared to cases. The prevalence was highest among those in the $30-39(1 \%)$ age group in the SCD population and the 40 - 49 age group (6.2\%) in the control group. Overall, the rate of HIV increased with age. Similarly, there was no difference in the rate of HCV infection between by gender within the two groups, but there was a non-significant trend toward higher prevalence among the female controls (0.8\%) compared to the cases $(0.4 \%)$. The overall rate of HCV infection among the 2034 participants was $1.6 \%$ (Table 3). The $20-29$ age group had the highest HCV prevalence (2.4\%) among those with SCD, while among those without SCD the prevalence was highest among those $\geq 50$ (4.0\%) and $20-29$ (3.5\%) of age.

The overall prevalence of HBV infection was $6.1 \%$ however, there was no significant difference in the prevalence of HBV infection by gender both within ( $\mathrm{p}$ $=0.32, \mathrm{p}=0.99$ and between $(\mathrm{p}=0.41)$ the groups. Table 4 shows the distribution of HBV among study participants by gender and age. Although the prevalence was higher among males (7.4\%) than females (5.5\%) in the control group, the difference was not significant. However, there was a significant difference in the prevalence of HBV by age within the two groups $(\mathrm{p}=0.001)$. The prevalence of HBV infection was highest among controls (13.1\%) and cases $(11.1 \%)$ in the 30 - 39 age group. Overall, the prevalence of all three infections was higher in the adult population compared with the pediatric population (Figure 2), although this difference was not significant for HIV infection. Figure 3 shows the overall distribution of HIV, HBV and HCV infection by age. The age groups with the highest prevalence were $20-29,30-39$ and $40-49$ for HCV, HBV and HIV, respectively.

Table 3. Distribution of HCV among individuals with or without SCD in Southwestern Nigeria by gender and age group.

\begin{tabular}{|c|c|c|c|c|c|c|c|c|}
\hline & & \multicolumn{2}{|c|}{ CASES } & \multicolumn{2}{|c|}{ CONTROL } & \multicolumn{2}{|c|}{ TOTAL } & \multirow[t]{2}{*}{$p$ value } \\
\hline & & $\begin{array}{c}\text { No } \\
\text { Tested }\end{array}$ & $\begin{array}{l}\text { No (\%) } \\
\text { positive }\end{array}$ & No Tested & $\begin{array}{l}\text { No (\%) } \\
\text { positive }\end{array}$ & No Tested & $\begin{array}{l}\text { No (\%) } \\
\text { positive }\end{array}$ & \\
\hline \multirow{3}{*}{ Gender } & Male & 527 & $6(1.1)$ & 528 & $12(2.3)$ & 1055 & $18(1.7)$ & 0.23 \\
\hline & Female & 490 & $4(0.8)$ & 489 & $10(2.0)$ & 979 & $14(1.4)$ & 0.12 \\
\hline & Total & 1017 & $\begin{array}{l}10(1.0) \\
p=0.75\end{array}$ & 1017 & $\begin{array}{l}22(2.2) \\
p=0.83\end{array}$ & 2034 & $\begin{array}{l}32(1.6) \\
p=0.72\end{array}$ & 0.048 \\
\hline \multirow{7}{*}{$\begin{array}{l}\text { Age } \\
\text { group }\end{array}$} & $0-9$ & 305 & $2(0.7)$ & 344 & $3(0.9)$ & 649 & $5(0.8)$ & 0.99 \\
\hline & $10-19$ & 346 & $2(0.6)$ & 330 & $9(2.7)$ & 676 & $11(1.6)$ & 0.03 \\
\hline & $20-29$ & 207 & $5(2.4)$ & 201 & $7(3.5)$ & 408 & $12(2.9)$ & 0.57 \\
\hline & $30-39$ & 99 & $1(1.0)$ & 84 & $1(1.2)$ & 183 & $2(1.1)$ & 0.99 \\
\hline & $40-49$ & 37 & $0(0.0)$ & 33 & $1(3.0)$ & 70 & $1(1.4)$ & 0.47 \\
\hline & $\geq 50$ & 23 & $0(0.0)$ & 25 & $1(4.0)$ & 48 & $1(2.1)$ & 0.99 \\
\hline & Total & 1017 & $\begin{array}{l}10(1.0) \\
\mathrm{p}=0.39\end{array}$ & 1017 & $\begin{array}{l}22(2.2) \\
\mathrm{p}=0.16\end{array}$ & 2034 & $\begin{array}{l}32(1.6) \\
p=0.12\end{array}$ & 0.048 \\
\hline
\end{tabular}


Table 4. Distribution of HBV infection among individuals with or without SCD in Southwestern Nigeria by gender and age group.

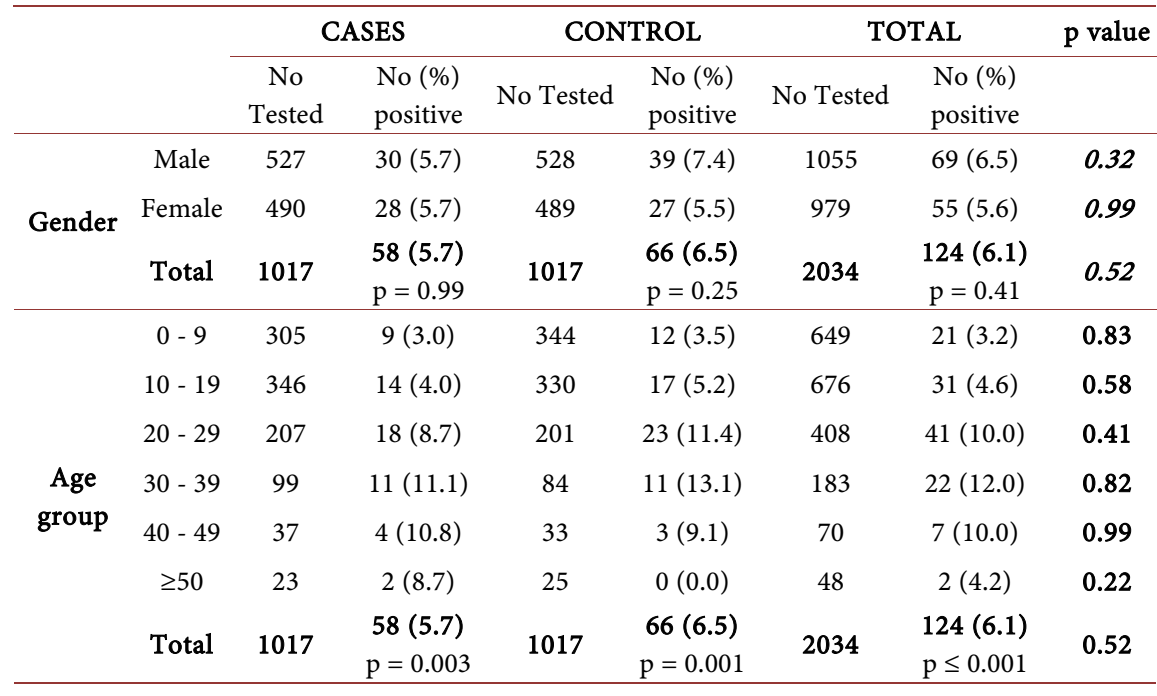

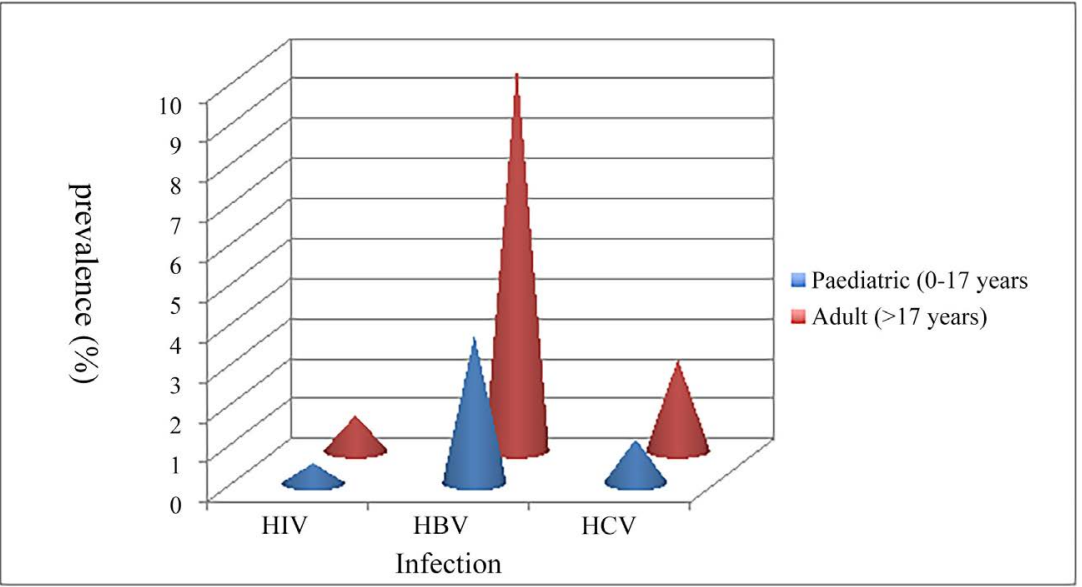

Figure 2. Distribution of HIV, HBV \& HCV Infection among the adult and pediatric participants.

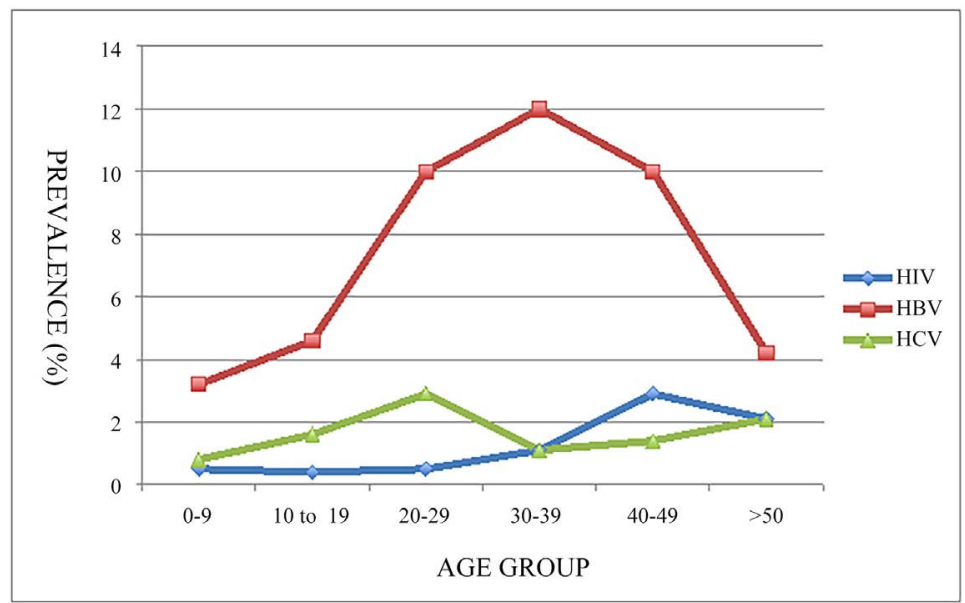

Figure 3. Prevalence of HIV, HBV \& HCV by age of study participants (cases \& controls). 
Although there was a trend toward higher prevalence of HIV, HBV and HCV in those with a history of blood transfusion among the SCD population, these differences were not significant. About 30\% (620/2034) of the study participants had history of blood transfusion. Table 5 shows the relationship between HIV, $\mathrm{HBV}$ and HCV and history of blood transfusion among the study population. In the control group the prevalence of infection was slightly higher among those with no history of blood transfusion, although the difference was also not significant. The prevalence of $\mathrm{HBV}$ and $\mathrm{HCV}$ infection was higher in those who received blood transfusion among the SCD cases, while the reverse was true among controls, although not statistically significant. Only $28.6 \%$ of the study population reported history of receiving hepatitis $B$ vaccine. Figure 4 shows the distribution of $\mathrm{HBV}$ infection by $\mathrm{HBV}$ vaccination status. Overall, the prevalence of

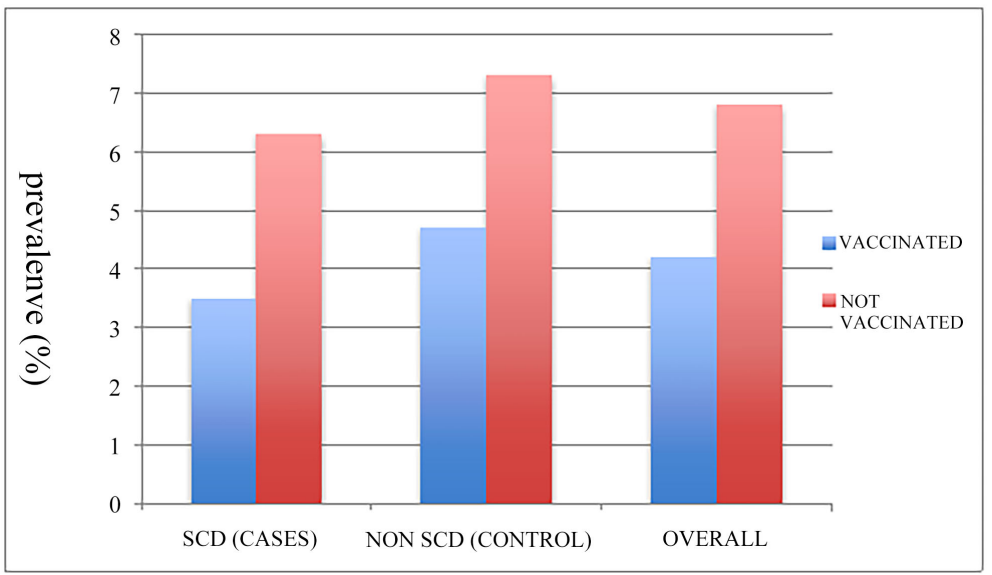

Figure 4. Distribution of HBV infection by Vaccination status in Cases and Controls.

Table 5. Distribution of HIV, HBV and HCV by history of blood transfusion among individuals with or without SCD in Southwestern Nigeria.

\begin{tabular}{|c|c|c|c|c|c|c|c|c|}
\hline \multirow[b]{2}{*}{ Infection } & \multirow{2}{*}{$\begin{array}{l}\text { Transfusion } \\
\text { Status }\end{array}$} & \multicolumn{2}{|c|}{ CASES } & \multicolumn{2}{|c|}{ CONTROL } & \multicolumn{2}{|c|}{ TOTAL } & \multirow[t]{2}{*}{$p$ value } \\
\hline & & No Tested & $\begin{array}{l}\text { No (\%) } \\
\text { positive }\end{array}$ & No Tested & $\begin{array}{l}\text { No (\%) } \\
\text { positive }\end{array}$ & No Tested & $\begin{array}{l}\text { No (\%) } \\
\text { positive }\end{array}$ & \\
\hline \multirow{3}{*}{ HIV } & Transfused & 566 & $1(0.2)$ & 54 & $0(0.0)$ & 620 & $1(0.2)$ & 0.99 \\
\hline & Not transfused & 451 & $1(0.2)$ & 963 & $11(1.1)$ & 1414 & $12(0.8)$ & 0.12 \\
\hline & Total & 1017 & $\begin{array}{c}2(0.2) \\
p=0.99\end{array}$ & 1017 & $\begin{array}{l}11(1.1) \\
p=0.99\end{array}$ & 2034 & $\begin{array}{l}13(0.6) \\
p=0.13\end{array}$ & 0.02 \\
\hline \multirow{3}{*}{$\mathrm{HBV}$} & Transfused & 566 & $34(6.0)$ & 54 & $3(5.6)$ & 620 & $37(6.0)$ & 0.99 \\
\hline & Not transfused & 451 & $24(5.3)$ & 963 & $63(6.5)$ & 1414 & $87(6.2)$ & 0.41 \\
\hline & Total & 1017 & $\begin{array}{l}58(5.7) \\
p=0.69\end{array}$ & 1017 & $\begin{array}{l}66(6.5) \\
p=0.99\end{array}$ & 2034 & $\begin{array}{c}124(6.1) \\
p=0.92\end{array}$ & 0.52 \\
\hline \multirow{3}{*}{$\mathrm{HCV}$} & Transfused & 566 & $6(1.1)$ & 54 & $0(0.0)$ & 620 & $6(1.0)$ & 0.99 \\
\hline & Not transfused & 451 & $4(0.9)$ & 963 & $22(2.3)$ & 1414 & $26(1.8)$ & 0.09 \\
\hline & Total & 1017 & $\begin{array}{l}10(1.0) \\
p=0.99\end{array}$ & 1017 & $\begin{array}{l}22(2.2) \\
p=0.63\end{array}$ & 2034 & $\begin{array}{l}32(1.6) \\
p=0.18\end{array}$ & 0.048 \\
\hline
\end{tabular}


HBV infection was significantly higher $(\mathrm{p}=0.03)$ among the non-vaccinated participants when compared with those who had history of $\mathrm{HBV}$ vaccination. Although the difference was not significant when considered as individual groups (i.e. cases or control), the prevalence was still higher among non-vaccinated cases $(6.3 \%$ vs $3.5 \%)$ and control $(7.3 \%$ vs $4.7 \%)$.

Overall, the rate of co-infection found in this study was $0.2 \%(4 / 2034)$. Three of these individuals were positive for both $\mathrm{HBV}$ and $\mathrm{HCV}$, giving an $\mathrm{HBV} / \mathrm{HCV}$ co-infection rate of $0.15 \%$, while one was positive for both $\mathrm{HBV}$ and $\mathrm{HIV}$, for an $\mathrm{HIV} / \mathrm{HBV}$ co-infection rate of $0.05 \%$. HIV-HCV coinfection or triple infection were not found in any of the participants. All coinfections were found among those with SCD, and 3 (75\%) had history of blood transfusion.

\section{Discussion}

Based on our review of the literature, this is the only case control study on HIV, $\mathrm{HBV}$ and HCV involving a large number of individuals with SCD, from SubSaharan Africa. Nigeria has the highest burden of SCD in the world with a prevalence of $2 \%-3 \%$ in the general population [2]. In a study carried out among a similar population in Ile-Ife, Nigeria, only 82 SCD and 90 sex and gender-matched controls were enrolled in the study [27]. The large sample size in this study increases the quality, accuracy, reliability of the data generated, and reduces the margin of error, making extrapolation into the larger population more representative.

The overall prevalence of HIV infection in this study was $0.6 \%$. This is lower than the prevalence among the general population in Nigeria [28]. This could be relevant to a higher preponderance of infection from some other states. However, it is within the range of HIV infection rates previously reported in Oyo state. According to the result of National HIV Sentinel Survey, the prevalence of HIV infection in Oyo State ranged from $0.2 \%-2.1 \%$ in the 2012 survey and a mean of $0.9 \%$ in the recent Nigeria HIV/AIDS Indicator and Impact Survey (NAIIS) [29]. This is also lower than reported among some other population groups in Ibadan [30] [31]. Although the rate of blood transfusion was significantly higher among the SCD patients than the control group in this study, the prevalence of HIV was significantly lower in the SCD patients than those without SCD, similar to the results from the National Programme on Immunization. This finding is also similar to the finding of a study in the US where the prevalence of HIV infection among SCD patients was $1.5 \%$ compared to $3.3 \%$ among those without SCD [32].

Recent studies have shown that SCD is associated with decreased HIV infection [32] [33]. This could be attributed to the enhanced immune defense in SCD [32] [33] or up regulation of inflammation, iron metabolism and immunologic changes in SCD that are not favorable for HIV replication [34] in association with expected precaution by SCD patients on sexual issues. The CCR5D32 mutant allele has been shown to confer resistance against HIV infection [35]. Al- 
though we did not investigate the presence of this allele in our study population, a study in Brazil [36] showed a higher rate of the CCR5D32 mutant allele among SCD patients $(5.1 \%)$ than healthy controls (1.3\%). However, the difference observed for SCD may be partly explained by the fact that SCD individuals have significantly less risky exposures for acquisition of HIV.

The HBV prevalence of $6.1 \%$ obtained in this study is lower than that previously reported in different populations in various parts of Nigeria [37] [38] [39]. In a study conducted among hospital patients in Lagos, the prevalence was 28.4\% [40], while a higher prevalence was found in another study carried out among blood donors and hairdressers in Ibadan, Oyo state [8] [41]. One of the reasons for the difference in the HBV rate between these studies and ours is the number of participants enrolled for the studies. While the sample sizes of those studies ranged from 100 to 500, the sample size for our study was 2034. The prevalence of HBV among the SCD patients (5.7\%) was lower than the prevalence of HBV among the controls (6.5\%), but the difference was not statistically significant. The prevalence of HBV in the SCD population in our study is lower than previously reported among SCD patients in Nigeria [5] [27]. The lower prevalence of HBV infection found in our study may be due to the preventive effect of HBV vaccine introduced into the National Programme on Immunization (NPI) in 2004, i.e., 15 years before this study [21]. This explanation is further supported by the fact that the prevalence of $\mathrm{HBV}$ infection was significantly lower in children younger than 18 years (3.7\%) compared with adults (9.7\%). The prevalence of HBV infection was also lower among vaccinated SCD patients and controls than in the unvaccinated participants.

In a review article on the status of HBV control in Africa region, Breakwell et al. [42] reported HBV vaccination coverage among children in Nigeria of $56 \%$ in 2015. This coverage is expected to have increased by the time of our study. Also, a study conducted using samples collected in the pre- and post-HBV vaccination era showed a reduction in the prevalence of HBV infection from $4.6 \%$ to $2.0 \%$ [43] among residents in a rural community in Nigeria. Breakwell et al. [42] reviewed 26 publications on HBV infection among various populations and locations in Nigeria and reported a median prevalence of $6.9 \%$, similar to the overall HBV prevalence of $6.1 \%$ found in our study.

According to the WHO an estimated 71 million people are chronically infected with HCV, with about $20 \%$ of these infections occurring in Africa [16] [44]. The global incidence of HCV was 23.7 cases per 100,000 population (95\% uncertainty interval; range 21.3 - 28.7) with an estimated 1.75 million new HCV infections diagnosed in 2015. The overall prevalence of HCV found in this study was $1.6 \%$. This is similar to the prevalence of HCV found among the general population in Nigeria, ranging from $1.5 \%$ to $2.5 \%$ [45]. This is also within the range of the estimated prevalence of HCV infection in West Africa [46]. We found that the prevalence of HCV was lower among those with SCD than those without SCD. However, it is lower than the prevalence of HCV reported among SCD 
patients in different parts of the country. For example, Lesi and Kehinde [47] found a prevalence of 5\% among SCD patients in Lagos, Omote et al. [48] reported a prevalence of 5\% in SCDs in Jalingo, Taraba state, and Ejiofor found a prevalence of 5\% among SCD in Benin City [49]. In a previous study among 180 SCD samples collected from patients in 1998 in Ibadan, by Fasola et al. [5] reported an $\mathrm{HCV}$ prevalence of $7.2 \%$. The difference in the prevalence found in this current study and our previous study of about 20 years ago may be an indication of the improvement in blood safety over the years. Prior to the Fasola study [5], HCV screening was not routinely incorporated into blood donation services in the country. In addition, the relatively small sample size may have contributed to the higher rate reported in the previous studies. The overall (1.6\%) prevalence of HCV among those with SCD (1.0\%) and those without SCD (2.2\%) found in this study are higher than the prevalence of $0.4 \%$ found among 1572 undergraduate students of a University in Oyo State, Nigeria [50]. It is also higher than the $0.8 \%$ reported among HIV negative individuals in a tertiary hospital in Lagos. [40]

Although the difference was not significant, a higher prevalence of HCV infection was found among the never transfused than those with history of blood transfusion. This is similar to the findings of Lesi and Kehinde [47], who reported a higher prevalence of HCV infection among the never transfused (7\%) than the transfused (5\%) among SCD patients in Lagos, Nigeria. Some researchers suggested that blood transfusion may not be the major mode of transmission of HCV [41] [47]. The finding of this study seems to support this suggestion which is further corroborated by our yet to be published data that showed that certain lifestyles predispose to TTIs more than history of blood transfusion. This may also explain why the prevalence of $\mathrm{HCV}$ is lower among SCD patients than the controls, even though the history of blood transfusion was significantly higher among those with SCD than the control group. However, in a study on the prevalence of antibodies to HCV among Nigerian patients with HIV infection, Inyama et al. [51] reported a higher prevalence of HCV infection among those with history of blood transfusion.

All three infections were lower in the pediatric $(<18$ years) than the adult $(>18$ years) population. It is well known that for viruses that cause chronic or latent infection, the prevalence of infection increases with age due to cumulative infection [52]. This, together with increased availability of vaccine for HBV, prevention of mother-to-child transmission (PMTCT) programmes for HIV, and improvement in screening of blood for transfusion may explain the lower prevalence of all three infections in the pediatric population. However, it must be noted that the prevalence of the three infections in this study were higher than what has been reported in some other countries. In a study conducted among SCD patients in Oman by Alkindi et al. [11], a prevalence of $0 \%, 2.3 \%$ and $12.6 \%$ were reported for HIV, HBV and HCV infections, respectively. A lower prevalence of HBV (1\%) and HCV (0.5\%) was also reported among apparently healthy preg- 
nant women in Ayingba [53], although the prevalence of HIV infection in their study was higher. Al-kadassy et al. (2018) also reported a lower prevalence of HIV (0\%), HBV (3.3\%) and HCV (0.8\%) among SCD patients in Hodeidah City, Yemen [54].

Co-infection of HIV, HBV and HCV infections are severe global public health problems, particularly in resource limited countries in sub-Saharan Africa where all three viruses are prevalent [38]. The three viruses share common route of transmission including sexual, mother-to-child, blood product, and co-infection is known to be associated with increased morbidity and mortality [25] [38] [43]. This makes detection of the infections in an individual a priority. Different rates of co-infection with these viruses have been reported in various populations in different parts of the country. The rate of $0.15 \%$ and $0.05 \%$ obtained respectively for $\mathrm{HBV} / \mathrm{HCV}$ and $\mathrm{HCV} / \mathrm{HIV}$ coinfection is low compared to previous reports in the country. Fasola et al. [5] reported an HBV/HCV coinfection rate of $7.2 \%$ among SCD patients in Ibadan, while Omote et al. [48] found an HBV/HCV prevalence of $1 \%$ among patients attending a tertiary hospital in Taraba state. However, the results of our study are similar to those of a study on HIV, HBV and HCV among pregnant women in Anyigba, Nigeria, in which an HIV/HCV coinfection rate of $0.5 \%$ was found [53]. Also similar to our study, the Anyigba study did not find anyone co-infected with all three viruses. In summary, the rate of HIV in this study is similar to the prevalence of $0.9 \%$ for Oyo State reported in the recent NAIIS [28]. The lower prevalence of HIV, HBV and HCV infection among SCD patients compared to earlier reports of about 2 decades ago suggests an improvement in the transfusion safety measures in the region. Furthermore, the prevalence of HBV and HCV found in this study are higher than observed in other reports among different populations and regions of Nigeria as well as other countries.

\section{Limitation}

The markers used for detection of HBV infection in this study measured current or ongoing infection, hence we are unable to identify individuals who were exposed to HBV but cleared the infection. Anti-HBs is a marker of previous infection, however it is challenging to differentiate anti-HBs produced in response to natural infection and that produced in response to vaccination.

\section{Conclusion}

The prevalence of HIV, HBV and HCV infection among SCD patients when compared with prevalence reported about a decade ago in the same population indicates an improvement in the transfusion safety measures in the region. However, the prevalence of HBV and HCV found in this study is still relatively high when compared with reports from some other regions of the world. There is therefore a need for continued surveillance and subsidized cost of drugs for treatment of these infections, especially for SCD patients who already have a compromised 
immunity. In addition, it is important to strengthen the preventive measures i.e. availability of vaccine for $\mathrm{HBV}$, prevention of mother-to-child transmission (PMTCT) programmes for HIV, and improvement in screening of blood for transfusion in order to further reduce the rate of these infections in the study population. We also recommend that SCD patients be tested regularly for the presence of these viruses especially in communities with less rigorous blood screening so that infection can be detected early, and appropriate interventions administered to positive individuals. In addition, other regions or countries with higher frequencies of HBV should pay more attention to the efficiency of their immunization program and their lifestyles to further reduce the level of these infections in the SCD and other at-risk populations.

\section{Acknowledgements}

Funding for this study was provided by GILEAD SCIENCES, USA through the Sickle Cell Hope Alive Foundation (SCHAF) as the Institution and Sponsor. We appreciate the study participants, staff of the various health facilities, gatekeepers at the various communities as well as the field, laboratory, and data staff.

\section{Authors' Contributions}

Conceptualization AGF, Study Design AGF, GNO, OMA; Methodology AGF, GNO, FF, AO, OAB; Data analyses \& data cleaning OMA; all authors provided critical revisions to the manuscript and do accept responsibility for the content of the article.

\section{Consent to Participate}

All participants provided written informed consent to participate in the study.

\section{Ethical Approval}

The study proposal was submitted by Sickle Cell Hope Alive Foundation (SCHAF) to the Joint Ethics Committee of the University of Ibadan/University College Hospital, Ibadan with an IRB Approval \# UI/EC/17/0400.

\section{Funding Disclosure}

GILEAD SCIENCES, USA provided Funding for this study through Sickle Cell Hope Alive Foundation (SCHAF), Nigeria. Grant \# IN-EU-334-4551. However, the GILEAD SCIENCES had no role in the study design, data collection and analysis, decision to publish or preparation of the manuscript.

\section{Data Sharing}

The data that support the findings of this study are available on request from the corresponding author. The data are not publicly available due to privacy or ethical restrictions. 


\section{Conflicts of Interest}

The authors declare no conflicts of interest regarding the publication of this paper.

\section{References}

[1] Herrick, J.B. (1910) Peculiar Elongated and Sickle Shape Red Blood Corpuscles in a Case of Severe Anaemia. Archives of Internal Medicine, 6, 517-521. https://doi.org/10.1001/archinte.1910.00050330050003

[2] Akinyanju. O. (1989) A Profile of Sickle Disease in Nigeria. Annals of the New York Academy of Sciences, 565, 126-136. https://doi.org/10.1111/j.1749-6632.1989.tb24159.x

[3] Falusi, A.G., Esan, G.J.F., Ayyub, H. and Higgs, D.R. (1987) Alpha Thalassaemia in Nigerians: It's Interaction with Sickle Cell Disease. European Journal of Haematology, 38, 370-375. https://doi.org/10.1111/j.1600-0609.1987.tb00013.x

[4] World Health Organization (2006) Fifty-Ninth World Health Assembly. A59/9 Provisional Agenda Item 11.4.: Report by the Secretariat, Sickle Cell Anaemia.

[5] Fasola, F.A., Odaibo, G.N., Akenova, Y.A. and Olaleye, O.D. (2003) Hepatitis B and C Viral Marker in Patients with Sickle Cell Disease in Ibadan, Nigeria. African Journal of Medicine and Medical Sciences, 32, 293-295.

[6] Ocak, S., Kaya, H., Cetin, M., Gali, E. and Ozturk, M. (2006) Seroprevalence of Hepatitis B and Hepatitis C in Patients with Thalassemia and Sickle Cell Anemia in a Long-Term Follow-Up. Archives of Medical Research, 37, 895-898. https://doi.org/10.1016/j.arcmed.2006.04.007

[7] Odaibo G.N., Olaleye O. D. and Tomori O. (1998) Human Immunodeficiency Virus Types 1 and 2 Infection in Some Rural Areas of Nigeria. Romanian Journal of $\mathrm{Vi}^{-}$ rology, 49, 89-95.

[8] Fasola, F.A., Kotila, T.R. and Akinyemi, J.O. (2008) Trends in Transfusion-Transmitted Viral Infections in Ibadan, Nigeria. Intervirology, 51, 427-431.

https://doi.org/10.1159/000209671

[9] Adesina, O., Oladokun, A., Akinyemi, O., Adedokun, B., Awolude, O., Odaibo, G., Olaleye, D.O. and Adewole, I. (2010) Human Immuno-Deficiency Virus and Hepatitis B Virus Coinfection in Pregnancy at the University College Hospital, Ibadan. African Journal of Medicine and Medical Sciences, 39, 305-310

[10] Calderon, G.M., González-Velázquez, F., González-Bonilla, C.R., et al. (2009) Prevalence and Risk Factors of Hepatitis C Virus, Hepatitis B Virus, and Human Immunodeficiency Virus in Multiply Transfused Recipients in Mexico. Transfusion, 49, 2200-2207. https://doi.org/10.1111/j.1537-2995.2009.02248.x

[11] Alkindi, S., Al-Umairi, N., Jaju, S. and Pathare, A. (2019) Prevalence of Hepatitis B, Hepatitis C, and HIV in Multiply Transfused Sickle Cell Disease Patients from Oman. Mediterranean Journal of Hematology and Infectious Diseases, 11, Article ID: e2019058. https://doi.org/10.4084/mjhid.2019.058

[12] UNAIDS (2019) UNAIDS Data 2019. https://www.unaids.org/sites/default/files/media asset/2019-UNAIDS-data en.pdf

[13] WHO Guidelines on Hepatitis B and C Testing (2017) Background-Epidemiology and Natural History. World Health Organization, Geneva. https://www.ncbi.nlm.nih.gov/books/NBK442290/

[14] Jefferies, M., Rauff, B., Rashid, H., Lam, T. and Rafiq, S. (2018) Update on Global Epi- 
demiology of Viral Hepatitis and Preventive Strategies. World Journal of Clinical Cases, 6, 589-599. https://doi.org/10.12998/wjcc.v6.i13.589

[15] Petruzziello, A., Marigliano, S., Loquercio, G., Cozzolino, A. and Cacciapuoti, C. (2016) Global Epidemiology of Hepatitis C Virus Infection: An Up-Date of the Distribution and Circulation of Hepatitis C Virus Genotypes. World Journal of Gastroenterology, 22, 7824-7840. https://doi.org/10.3748/wjg.v22.i34.7824

[16] Polaris Observatory HCV Collaborators (2017) Global Prevalence and Genotype Distribution of Hepatitis C Virus Infection in 2015: A Modelling Study. The Lancet Gastroenterology and Hepatology, 2, 161-176. https://doi.org/10.1016/S2468-1253(16)30181-9

[17] Yaguo Ide, L.E. and Babatunde, S. (2015) Hepatitis, B.C. and Human Immunodeficiency Virus (HIV) Co-infection in Nigerian Children with Sickle Cell Anaemia. The Nigerian Health Journal, 15, 18-23.

[18] Omatola, C.A., Lawal, C., Omosayin, D.O., et al. (2019) Seroprevalence of HBV, HCV, and HIV and Associated Risk Factors among Apparently Healthy Pregnant Women in Anyigba, Nigeria. Viral Immunology, 32, 186-191.

https://doi.org/10.1089/vim.2018.0140

[19] Ezechi, O.C., Kalejaiye, O.O., Gab-Okafor, C.V., Oladele, D.A., Oke, B.O., Musa, Z.A., et al. (2014) Sero-Prevalence and Factors Associated with Hepatitis B and C Co-Infection in Pregnant Nigerian Women Living with HIV Infection. The Pan African Medical Journal, 17, 197. https://doi.org/10.11604/pamj.2014.17.197.2310

[20] Joanah, M.I., Henry, C.O., Iwasam, E.A., Imaobong, S.E. and Emmanuel, E.E. (2017) Asymptomatic Hepatitis C Infection in Nigerian Adolescents. EC Gastroenterology and Digestive System, 4, 113-118.

[21] World Health Organization (2016) Evidence Presented to SAGE. A Systematic Review of Monovalent Hepatitis B Vaccine Thermostability.

[22] Morano, J.P., Zelenev, A., Lombard, A., Marcus, R., Gibson, B.A. and Altice, F.L. (2014) Strategies for Hepatitis C Testing and Linkage to Care for Vulnerable Populations: Point-of-Care and Standard HCV Testing in a Mobile Medical Clinic. Journal of Community Health, 39, 922-934. https://doi.org/10.1007/s10900-014-9932-9

[23] Hutin, Y.J.-F., Bulterys, M. and Hirnschall, G.O. (2018) How Far Are We from Viral Hepatitis Elimination Service Coverage Targets? Journal of the International AIDS Society, 21, Article ID: e25050. https://doi.org/10.1002/jia2.25050

[24] Olubuyide, I.O., Aliyu, B., Olaleye, O.D., Ola, S.O., Olawuyi, F., Malabu, V.H., Odemuyiwa, S.O., Odaibo, G.N. and Cook, G.C. (1997) Hepatitis B and C and Hepatocellular Carcinoma (HCC). Transactions of the Royal Society of Tropical Medicine \& Hygiene, 91, 38-41. https://doi.org/10.1016/S0035-9203(97)90387-4

[25] Ola, S.O., Odaibo, G.N. and Olaleye, O.D. (2004) HCV and HBV Infections in Nigerian Patients with Liver Cirrhosis and Hepatocellular Carcinoma. Nigeria Quaterly Journal of Hospital Medicine, 14, 233-235.

https://doi.org/10.4314/nqjhm.v14i3.12728

[26] Odera, E.B., Kwobah, C., Stone, G., Some, F. and Vreeman, R.C. (2014) Sickle Cell Disease and HIV: A Case Highlighting Management Challenges for Children in a Resource-Limited Setting. Journal of the International Association of Providers of AIDS Care. https://doi.org/10.1177/2325957413508320

[27] Bolarinwa, R.A., Aneke, J.C., Olowookere, S.A. and Salau, L. (2015) Seroprevalence of Transfusion Transmissible Viral Markers in Sickle Cell Disease Patients and Healthy Controls in Ile-Ife, South-Western Nigeria: A Case-Control Study. Journal of Applied 
Hematology, 6, 162-167. https://doi.org/10.4103/1658-5127.171985

[28] National Agency for the Control of AIDS (NACA) (2019) The 2018 Nigeria HIV. AIDS Indicator and Impact Survey (NAIIS). https://naca.gov.ng/naiis-report/

[29] Nigerian Government Federal Ministry of Health (FMOH) (2012) National HIV SeroPrevalence Sentinel Survey.

[30] Ogunbosi, B.O., Oladokun, R.E., Brown, B.J. et al. (2011) Prevalence and Clinical Pattern of Paediatric HIV Infection at the University College Hospital, Ibadan, Nigeria: A Prospective Cross-Sectional Study. Italian Journal of Pediatrics, 37, 29. https://doi.org/10.1186/1824-7288-37-29

[31] Federal Republic of Nigeria Federal Ministry of Health (2012) National HIV \& AIDS and Reproductive Health Survey. Federal Republic of Nigeria Federal Ministry of Health.

http://nigeriahealthwatch.com/wp-content/uploads/bsk-pdf-manager/431 $2012 \mathrm{Na}$ tional HIV \& AIDS and Reproductive Health Survey (NARHS Plus II, 2012), FMOH Abuja 1172.pdf

[32] Nouraie, M., Nekhai, S. and Gordeuk, V.R. (2012) Sickle Cell Disease Is Associated with Decreased HIV but Higher HBV and HCV Comorbidities in U.S. Hospital Discharge Records: A Cross-Sectional Study. Sexually Transmitted Infections, 88, 528 533. https://doi.org/10.1136/sextrans-2011-050459

[33] Owusu, E.D., Visser, B.J., Nagel, I.M., Mens, P.F. and Grobusch, M.P. (2015) The Interaction between Sickle Cell Disease and HIV Infection: A Systematic Review. Clinical Infectious Diseases, 60, 612-626. https://doi.org/10.1093/cid/ciu832

[34] Kumari, N., Ammosova, T., Diaz, S., et al. (2016) Increased Iron Export by Ferroportin Induces Restriction of HIV-1 Infection in Sickle Cell Disease. Blood Advances, 1, 170-183. https://doi.org/10.1182/bloodadvances.2016000745

[35] de Silva, E. and Stumpf, M.P.H. (2004) HIV and the CCR5- $\triangle 32$ Resistance Allele. FEMS Microbiology Letters, 241, 1-12. https://doi.org/10.1016/j.femsle.2004.09.040

[36] Lopes, M.B., Santos, M.N., Faber, E.W., Bezerra, M.A.C., Hatzlhofer, B.L.D., Albuquerque, D.M., Zaccariotto, T.R., Ribeiro, D.M., Araújo, A.D.-S., Costa, F.F. and Sonati, M.F. (2014) The CCR5 32 Polymorphism in Brazilian Patients with Sickle Cell Disease. Disease Markers, 2014, Article ID: 678246. https://doi.org/10.1155/2014/678246

[37] Odaibo, G.N., Arotiba, J.T., Fasola, A.O., Obiechina, A.E., Olaleye, O.D. and Ajagbe, H.A. (2003): Prevalence of Hepatitis B Virus Surface Antigen (HBsAg) in Patients Undergoing Extraction at the University College Hospital, Ibadan. African Journal of Medicine and Medical Sciences, 32, 243-245.

[38] Otegbayo, J.A., Taiwo, B.O., Akingbola, T.S., Odaibo, G.N., Adedapo, K.S., Penugunda, S., Adewole, I.F., Olaleye, D.O., Murphy, R. and Kanki, P. (2008) Prevalence of Hepatitis B and C seropositivity in a Nigerian Cohort of HIV-Infected Patients. Annals of Hepatology, 7, 152-156. https://doi.org/10.1016/S1665-2681(19)31872-1

[39] Adeyemi, A.B., Enabor, O.O., Ugwu, I.A., Abraham, O.A., Bello, F.A. and Olayemi, O. (2014) Prevalence of Antenatal Hepatitis B Infection in Tertiary and Non-Tertiary Health Facilities in Ibadan, Nigeria. Nigerian Journal of Medicine, 23, 248-253.

[40] Balogun, T.M., Emmanuel, S. andOjerinde, E.F. (2012) HIV, Hepatitis B and C Viruses' Coinfection among Patients in a Nigerian Tertiary Hospital. The Pan African Medical Journal, 12, 1-6.

[41] Olusola, B.A., Gometi, E.A., Ogunsemowo, O., Olaleye, D.O. and Odaibo, G.N. (2017) High Rate of Hepatitis B Virus Infection among Hairdressers in Ibadan, Nigeria. Journal of Immunoassay \& Immunochemistry, 38, 322-332. 


\section{https://doi.org/10.1080/15321819.2016.1260585}

[42] Breakwell, L., Tevi-Benissan, C., Childs, L., Mihigo, R. and Tohme, R. (2017) The Status of Hepatitis B Control in the African Region. The Pan African Medical Journal, 27, 17. https://doi.org/10.11604/pamj.supp.2017.27.3.11981

[43] Odusanya, O.O., Alufohai, E., Meurice, F.P. and Ahonkhai, V.I. (2011) Five-Year Post Vaccination Efficacy of Hepatitis B Vaccine in Rural Nigeria. Human Vaccines, 7, 625-629. https://doi.org/10.4161/hv.7.6.14990

[44] World Health Organization (2018) Progress Report on Access to Hepatitis C Treatment: Focus on Overcoming Barriers in Low- and Middle-Income Countries, March 2018. World Health Organization, Geneva.

[45] Forbi, J.C., Purdy, M.A., Campo, D.S., et al. (2012) Epidemic History of Hepatitis C Virus Infection in Two Remote Communities in Nigeria, West Africa. Journal of General Virology, 93, 1410-1421. https://doi.org/10.1099/vir.0.042184-0

[46] Obadahn, O. and Kamal, S. (2018) Hepatitis C Virus in Sub-Saharan Africa. In: Kamal, S.M., Ed., Hepatitis C in Developing Countries, Elsevier, Berlin, 71-81. https://doi.org/10.1016/B978-0-12-803233-6.00007-2

[47] Lesi, O. and Kehinde, M. (2003) Hepatitis C Virus Infection in Patients with Sickle Cell Anaemia at the Lagos University Hospital. The Nigerian Postgraduate Medical Journal, 10, 79-83.

[48] Omote, V., Kashibu, E., Ojumah, I., Adda, D., Etaghene, J. and Ukwamedua, H. (2018) Serological Screening of Hepatitis B Virus and Hepatitis C Virus among Patients Attending a Tertiary Hospital in Jalingo, Taraba State, Nigeria. Saudi Journal for Health Sciences, 7, 167-171. https://doi.org/10.4103/sjhs.sjhs $39 \quad 18$

[49] Ejiofor, O.S., Emechebe, G.O., Igwe, W.C., Ifeadike, C.O. and Ubajaka, CF. (2010) Hepatitis C Virus Infection in Nigerians. Nigerian Medical Journal, 51, 173-176.

[50] Jemilohun, A.C., Oyelade, B.O. and Oiwoh, S.O. (2014) Prevalence of Hepatitis C Virus Antibody among Undergraduates in Ogbomoso, Southwestern Nigeria. African Journal of Infectious Diseases, 8, 40-43. https://doi.org/10.4314/ajid.v8i2.5

[51] Inyama, P., Uneke, C., Anyanwu, G., Njoku, M., Idoko, J. and Idoko, J. (2005) Prevalence of Antibodies to Hepatitis C Virus among Nigerian Patients with HIV Infection. Online Journal of Health \& Allied Sciences, 4, 1-6.

http://www.ojhas.org/issue14/2005-2-2.htm

[52] Salu, O.B., Oyefolu, A.O.B., Gbadegesin, A., James, A.B., Oke, B.O., Ashaka, O.S., Anjorin, A.A., Akinyemi, K.O. and Omilabu, S.A. (2018) Co-Infection of Hepatitis $\mathrm{B}$ and $\mathrm{C}$ Viruses among Human Immunodeficiency Virus Infected Children in Lagos, Nigeria. African Journal of Clinic and Experimental Microbiology, 1. https://doi.org/10.4314/ajcem.v19i2.8

[53] Nwankwo, E.O., Lawal, A.M. and Abba, M. (2016) Seroprevalence of Hepatitis C Virus (HCV) Antibodies in Pregnant Women in Anyigba, Kogi State, North Central Nigeria. African Journal of Clinical and Experimental Microbiology, 17. https://doi.org/10.4314/ajcem.v17i3.10

[54] Al-kadassy, A.M., Alkadasi, M.N., Puttauah, E.T., Naji, A.S., Alhwthyfi, A. and Eleewah, K. (2018) Prevalence of Hepatitis B,C and HIV among Sickle Cell Disease Patients in Hodeidah City, Yemen. Journal of Bio Innovation, 7, 114-125. 